\title{
Sistem Pendukung Keputusan Penyeleksian Mahasiswa Berprestasi Menggunakan Metode Naive Bayes Berbasis Web
}

\author{
Fredy Perdana Anggara Selfiyan', Dimas Wahyu Wibowo², Adn Maulidya Handah Putri ${ }^{3}$, Haryo \\ Bagus Setyawan ${ }^{4}$, Okta Chandika Salsabila ${ }^{5}$ \\ Politeknik Negeri Malang \\ e-mail: ${ }^{1}$ fredy@polinema.ac.id, ${ }^{2}$ dimas.w@polinema.ac.id, ${ }^{3}$ putriadn@gmail.com, \\ ${ }^{4}$ haryobagus14@gmail.com, ${ }^{5}$ chandika.salsabila@gmail.com \\ Diajukan: 29 Oktober 2019; Direvisi: 25 November 2019; Diterima: 25 November 2019
}

\begin{abstract}
Abstrak
Penyeleksian mahasiswa berprestasi adalah suatu kegiatan untuk memilih beberapa mahasiswa yang berprestasi baik di bidang akademis ataupun non akademis. Kegiatan penyeleksian mahasiswa berprestasi merupakan kegiatan yang dilakukan setiap tahun. Di dalam proses penyeleksian mahasiswa berprestasi dibentuk sebuah tim yang akan menilai kandidat mahasiswa berprestasi. Namun dalam proses penyeleksian masih dilakukan secara manual sehingga memerlukan waktu yang cukup lama untuk mengolah data. Selain itu, ketidaksempurnaan informasi juga merupakan salah satu faktor yang membuat waktu pengolahan data yang cukup lama. Berdasarkan hal tersebut pada tugas ini dibangun sistem pendukung keputusan yang digunakan untuk penyeleksian mahasiswa berprestasi. Metode yang digunakan adalah metode Naive Bayes. Sistem pendukung keputusan ini dibentuk dengan bahasa pemrograman PHP dan database SQL. Sistem akan mengambil input berupa data mahasiswa yang terdiri dari nomor induk mahasiswa, nama, jenis kelamin, program studi, jurusan kuliah, semester, nilai indeks prestasi (IP), dan jumlah piagam baik di bidang akademis maupun non-akademis yang dimiliki oleh mahasiswa. Berdasarkan input tersebut, sistem akan memberikan output yang memutuskan apakah seorang mahasiswa layak mendapatkan gelar mahasiswa berprestasi atau tidak. Dengan demikian sistem dapat digunakan untuk membantu dalam penentuan gelar mahasiswa berprestasi.
\end{abstract}

Kata kunci: Mahasiswa berprestasi, Penyeleksian, Naive Bayes.

\begin{abstract}
Outstanding student selection is an activity to choose several students achievers both academically and non-academically. Outstanding student selection activities are activities that was held every year. In the selection process of selecting outstanding students, a team will be formed that will evaluate the student candidates. But in the selection process is still done manually so it requires a long time to process data. Beside that, imperfection of information is also one factor that makes data processing time is quite long. Based on this task the system was built a decision support system are used to select outstanding students. Method that used is the Naive Bayes method. This decision support system was formed with the PHP programming language and SQL database. The system will take input in the data of the student consisting of a student ID number, name, gender, study program, college majors, semester, grade point, and the number of certificates both in academically and non-academically owned by students. Based on these inputs, the system will give output that decide a student get an outstanding student title or not. Therefore the system can be used to assist in the determination of the title of outstanding student.
\end{abstract}

Keywords: Outstanding students, Selection, Naive Bayes.

\section{Pendahuluan}

Perguruan tinggi merupakan jenjang pendidikan paling tinggi dalam sistem pendidikan nasional, maka perguruan tinggi menjadi acuan dalam mendorong perkembangan suatu bangsa [1]. Di dalam perguruan tinggi mencakup program diploma, sarjana, magister, spesialis dan doktor. Di dalam sebuah perguruan tinggi memiliki peserta didik yang disebut mahasiswa. Mahasiswa merupakan peserta didik pada jenjang Perguruan Tinggi [2].

Setiap perguruan tinggi selalu berupaya meningkatkan mutu internal agar dapat bersaing di dalam dunia perguruan tinggi. Salah satu upaya yang dilakukan adalah penyeleksian mahasiswa berprestasi setiap 
tahunnya. Mahasiswa berprestasi merupakan mahasiswa yang berhasil mencapai prestasi tertinggi baik akademis maupun non akademis [3]. Selama ini penyeleksian mahasiswa berprestasi dilakukan secara manual. Proses jalannya sistem penentuan mahasiswa berprestasi secara manual dimulai dari mengumpulkan data indeks prestasi mahasiswa dan jumlah piagam akademik maupun non-akademik yang dimiliki mahasiswa, kemudian data-data tersebut akan diolah oleh staf akademik kampus. Akan tetapi proses tersebut tidak efektif dan efisien karena memerlukan waktu pengolahan data yang cukup lama. Pengolahan data yang cukup lama ini diakibatkan oleh faktor ketidakpastian atau ketidaksempurnaan informasi dari data yang sedang diolah. Ini merupakan hal mendasar yang menjadikan proses pengambilan keputusan memiliki penyelesaian yang semakin kompleks dalam menentukan pilihan terbaik [4].

Selain itu, masalah lain yang bisa muncul pada penggunaan sistem penentuan mahasiswa berprestasi yang bersifat manual adalah kesalahan dalam pengolahan data, sehingga hasil yang diharapkan pada sistem tersebut pun menjadi kurang akurat.

Maka dari itu, diperlukan suatu sistem pendukung keputusan yang dapat membantu penentuan mahasiswa berprestasi. Ada banyak metode yang bisa digunakan dalam penerapan sistem pendukung keputusan untuk penentuan mahasiswa berprestasi, salah satunya menggunakan metode Weighted Product, yang menitikberatkan pada bobot dan kriteria untuk pembuatan keputusan. Sebelumnya sudah terdapat penelitian tentang sistem pendukung keputusan mahasiswa berprestasi menggunakan metode Weighted Product yang dilakukan oleh Muhammad Mukmin, Jabal Nur, dan L. M. Fajar Israwan dari program studi Teknik Informatika Universitas Dayanu Ikhsanuddin Baubau, Sulawesi Tenggara pada tahun 2018. Kriteria yang digunakan pada penelitian tersebut antara lain adalah nilai indeks prestasi kumulatif (IPK) dengan bobot 20\%, nilai Tugas Akhir dengan bobot 30\%, prestasi mahasiswa dengan bobot 25\%, dan nilai bahasa Inggris dengan bobot $25 \%$. Penelitian tersebut menghasilkan output berupa vektor, yang mana mahasiswa dengan nilai vektor tertinggi akan mendapatkan gelar mahasiswa berprestasi.

Selain itu, metode lain yang dapat digunakan untuk penerapan sistem pendukung keputusan mahasiswa berprestasi adalah metode Naïve Bayes. Berbeda dengan metode Weighted Product, metode Naïve Bayes lebih menitikberatkan pada perhitungan frekuensi kombinasi nilai input data untuk menghasilkan probabilitas atau peluang pada pengambilan keputusan. Metode yang dipilih dalam penelitian sistem pendukung keputusan untuk penentuan mahasiswa berprestasi ini yaitu metode Naïve Bayes.

Dengan menggunakan metode Naive Bayes dapat memprediksi dan memperbaiki data lama dan menghasilkan data baru yang dapat digunakan untuk mengambil sebuah keputusan dengan asumsi yang sangat kuat dari masing-masing kejadian. Model ini digunakan untuk mengklasifikasikan layak atau tidaknya seorang mahasiswa mendapatkan gelar mahasiswa berprestasi [5].

\section{Metode Penelitian}

Metode yang digunakan dalam penelitian ini yaitu menggunakan metode Naive Bayes.

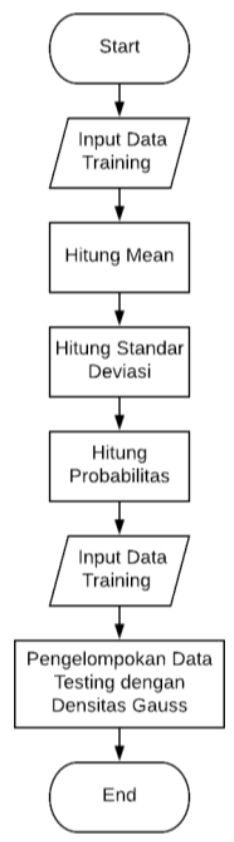

Gambar 1. Flowchart algoritma Naive Bayes. 
Berdasarkan gambar flowchart di atas, sistem dimulai dengan memasukkan data training yang berupa nilai Indeks Prestasi Kumulatif (IPK) dan jumlah piagam akademik maupun non-akademik mahasiswa, kemudian menghitung mean, standar deviasi, dan probabilitas. Hasil dari perhitungan data training akan digunakan sebagai acuan data testing sesuai dengan algoritma Naive bayes. Selanjutnya dilakukan input data testing yang juga berupa nilai Indeks Prestasi Kumulatif (IPK) dan jumlah piagam mahasiswa, lalu menghitung probabilitas menggunakan densitas Bayes dengan input nilai mean dan standar deviasi yang telah didapatkan dari perhitungan sebelumnya. Hasil dari perhitungan akan menghasilkan keputusan mahasiswa berprestasi.

\subsection{Data Training}

Data training adalah data yang digunakan untuk perhitungan probabilitas dari data berdasarkan data pembelajaran yang dilakukan [6]. Data training merupakan data yang sebelumnya sudah ada sesuai dengan fakta. Data training yang digunakan pada aplikasi ini didapatkan dari data penilaian mahasiswa Politeknik Negeri Malang jurusan Teknologi Informasi angkatan tahun 2015 sejumlah 249 data. Cara memasukkan data training pada aplikasi ini dilakukan dengan cara manual ke database melalui PhpMyAdmin.

\subsection{Perhitungan dengan Naive Bayes}

Pada sistem ini digunakan algoritma Naive Bayes. Naive Bayes adalah sebuah pengklasifikasian sederhana yang menghitung sekumpulan probabilitas dengan menjumlahkan frekuensi kombinasi nilai dari data set yang diberikan [7]. Algoritma ini dikemukakan oleh ilmuwan Inggris yaitu Thomas Bayes, yaitu memprediksi peluang di masa depan berdasarkan pengalaman di masa sebelumnya [8]. Dalam program digunakan rumus Bayes berikut [9]:

$$
P(A \mid B)=(P(B \mid A) * P(A)) / P(B)
$$

Keterangan :

1. $\mathrm{P}(\mathrm{A} \mid \mathrm{B})$ adalah peluang data $\mathrm{B}$ pada data $\mathrm{A}$.

2. $\mathrm{P}(\mathrm{B} \mid \mathrm{A})$ adalah peluang pada data A, pada data B muncul pada kategori tersebut.

3. $\mathrm{P}(\mathrm{A})$ adalah peluang dari data yang diberikan, dibandingkan dengan data lainnya yang dianalisis.

4. P ( B ) adalah peluang dari data tersebut secara spesifik. Pada pengembangannya, P ( B ) dapat dihilangkan karena nilainya tetap atau konstan, sehingga saat dibandingkan dengan tiap data, nilai ini dapat dihapus.

Mean (rata-rata), Probabilitas (peluang) dan Standard Deviasi merupakan hal penting di dalam algoritma Naive bayes.

a. Mean adalah nilai rata-rata dari beberapa buah data . Nilai mean dapat ditentukan dengan membagi penjumlahan data yang ada dengan banyaknya data [10] .

$$
\mu=\frac{\mathrm{x} 1+\mathrm{x} 2+\mathrm{x} 3+\ldots+\mathrm{xn}}{n}
$$

Keterangan:

$\mu \quad$ : nilai rata-rata (mean)

$\mathrm{x}_{\mathrm{i}}$ : nilai $\mathrm{x}$ ke-i

n : jumlah sampel

Contoh perhitungan mean pada piagam:

Tabel 1. Tabel probabilitas piagam.

\begin{tabular}{lcc}
\hline$\#$ & Piagam & MAWAPRES \\
\hline 1 & 4 & $40 / 146$ \\
\hline 2 & 5 & $49 / 146$ \\
\hline 3 & 6 & $27 / 146$ \\
\hline 4 & 7 & $0 / 146$ \\
\hline 5 & 8 & $24 / 146$ \\
\hline 6 & 9 & $1 / 146$ \\
\hline 7 & 10 & $5 / 146$ \\
$\mu=\frac{\mathrm{x} 1+\mathrm{x} 2+\mathrm{x} 3+\ldots+\mathrm{xn}}{n}=\frac{40+49+27+0+24+1+5}{7}=\frac{146}{7}=20,857$
\end{tabular}

Sistem Pendukung Keputusan Penyeleksian Mahasiswa Berprestasi Menggunakan Metode Naive Bayes Berbasis Web (Fredy Perdana Anggara Selfiyan) 
b. Standar deviasi adalah nilai yang digunakan untuk menentukan tingkat sebaran data dalam sampel dan mengetahui sedekat apa titik data pada rata-rata nilai sampel [10].

Keterangan:

$$
\sigma=\sqrt{\frac{\sum_{i=1}^{n}\left(X_{i}-\mu\right)^{2}}{n-1}}
$$

$\sigma \quad$ : standar deviasi

$\mu \quad$ : nilai rata-rata $(m e a n)$

$\mathrm{x}_{\mathrm{i}} \quad$ : nilai x ke-i

n : jumlah sampel

Contoh perhitungan standar deviasi pada piagam:

Tabel 2. Tabel probabilitas piagam.

\begin{tabular}{ccc}
\hline$\#$ & Piagam & MAWAPRES \\
\hline 1 & 4 & $40 / 146$ \\
\hline 2 & 5 & $49 / 146$ \\
\hline 3 & 6 & $27 / 146$ \\
\hline 4 & 7 & $0 / 146$ \\
\hline 5 & 8 & $24 / 146$ \\
\hline 6 & 9 & $1 / 146$ \\
\hline 7 & 10 & $5 / 146$
\end{tabular}

$\sigma=\sqrt{\frac{\sum_{i=1}^{n}\left(X_{i}-\mu\right)^{2}}{n-1}}=\sqrt{\frac{(40-20,857)^{2}+(49-20,857)^{2}+\cdots+(5-20,857)^{2}}{7-1}}=\sqrt{\frac{2286.85}{6}}=\sqrt{381.14}=19.52$

c. Probabilitas adalah kemungkinan atau peluang dalam menentukan nilai dimasa mendatang [10].

Keterangan:

$$
P(A / B)=P(A) / P(B)
$$

$\mathrm{P}(\mathrm{A} \mid \mathrm{B})$ : peluang

$\mathrm{P}(\mathrm{A}) \quad$ : jumlah variabel tertentu contoh piagam

P(B) : jumlah total Mawapres/tidak Mawapres

Contoh perhitungan probabilitas pada piagam:

Tabel 3. Tabel data piagam.

\begin{tabular}{lcc}
\hline$\#$ & Piagam & MAWAPRES \\
\hline 1 & 4 & 40 \\
\hline 2 & 5 & 49 \\
\hline 3 & 6 & 27 \\
\hline 4 & 7 & 0 \\
\hline 5 & 8 & 24 \\
\hline 6 & 9 & 1 \\
\hline 7 & 10 & 5 \\
\hline & Jumlah & 146 \\
\hline
\end{tabular}

$\mathrm{P}(\mathrm{A} / \mathrm{B})=\mathrm{P}(\mathrm{A}) / \mathrm{P}(\mathrm{B})=\mathrm{P}(4$ Piagam $/ \mathrm{MAWAPRES})=40 / 146$

$\mathrm{P}(\mathrm{A} / \mathrm{B})=\mathrm{P}(\mathrm{A}) / \mathrm{P}(\mathrm{B})=\mathrm{P}(5$ Piagam $/$ MAWAPRES $)=49 / 146$

$\mathrm{P}(\mathrm{A} / \mathrm{B})=\mathrm{P}(\mathrm{A}) / \mathrm{P}(\mathrm{B})=\mathrm{P}(6$ Piagam $/ \mathrm{MAWAPRES})=27 / 146$

$\mathrm{P}(\mathrm{A} / \mathrm{B})=\mathrm{P}(\mathrm{A}) / \mathrm{P}(\mathrm{B})=\mathrm{P}(7 \mathrm{Piagam} / \mathrm{MAW} A P R E S)=0 / 146$

$\mathrm{P}(\mathrm{A} / \mathrm{B})=\mathrm{P}(\mathrm{A}) / \mathrm{P}(\mathrm{B})=\mathrm{P}(8$ Piagam $/$ MAWAPRES $)=24 / 146$

$\mathrm{P}(\mathrm{A} / \mathrm{B})=\mathrm{P}(\mathrm{A}) / \mathrm{P}(\mathrm{B})=\mathrm{P}(9$ Piagam $/$ MAW APRES $)=1 / 146$

$\mathrm{P}(\mathrm{A} / \mathrm{B})=\mathrm{P}(\mathrm{A}) / \mathrm{P}(\mathrm{B})=\mathrm{P}(10$ Piagam $/$ MAWAPRES $)=5 / 146$

\subsection{Data Testing}

Data testing merupakan data yang akan atau sedang terjadi dan dipergunakan sebagai bahan uji yang sebelumnya sudah didapatkan pada data training [6]. Data ini digunakan untuk mengklasifikasikan apakah mahasiswa tersebut termasuk mahasiswa berprestasi atau tidak. Data testing terdiri dari 7 data 
mahasiswa dan didapatkan dari data mahasiswa Politeknik Negeri Malang jurusan Teknologi Informasi tahun ajaran 2015 .

\subsection{Pengelompokan Data Testing dengan Densitas Gauss}

Karena perhitungan nilai-nilai saling berkaitan (kontinu) maka perlu digunakan fungsi densitas Gauss dengan rumus di bawah ini:

Keterangan:

$$
f(x)=\frac{1}{\sqrt{2} \pi \sigma} e^{\frac{-(x-\mu)^{2}}{2 \sigma^{2}}}
$$

$$
\begin{aligned}
& \mu: \text { mean } \\
& \sigma: \text { standar deviasi } \\
& \pi: 3,14 \\
& \text { e }: 2,7183
\end{aligned}
$$

Contoh perhitungan Densitas Gauss:

$$
f(x)=\frac{1}{\sqrt{2} \pi \sigma} e^{\frac{-(x-\mu)^{2}}{2 \sigma^{2}}}=\frac{1}{\sqrt{2} \cdot \pi \cdot 19,523000000000} e^{\frac{-(49,000000000000-20,857000000000)^{2}}{2 \cdot 19,523000000000^{2}}}=0,232346150770
$$

\section{Hasil dan Pembahasan}

Pengujian dilakukan dengan memasukkan data probabilitas Prodi, jenis kelamin, semester, jumlah piagam, dan IPK mahasiswa pada data Mawapres ataupun data mahasiswa yang tidak termasuk Mawapres ke dalam aplikasi. Data tersebut didapatkan dari hasil pengolahan data training. Pada pengolahan data training, penghitungan data probabilitas Prodi, jenis kelamin, dan semester dilakukan menggunakan rumus probabilitas. Sedangkan data probabilitas jumlah piagam dan IPK mahasiswa diperoleh dari hasil perhitungan densitas Gauss, karena data probabilitas jumlah piagam dan IPK mahasiswa menjadi acuan utama dalam penentuan mahasiswa berprestasi menggunakan algoritma Naïve Bayes. Selanjutnya data probabilitas Prodi, jenis kelamin, semester, jumlah piagam, dan IPK mahasiswa dikalikan satu sama lain sehingga menghasilkan nilai yang disebut likelihood. Apabila likelihood pada data Mawapres dan data mahasiswa bukan Mawapres sudah diperoleh, maka keduanya akan dijumlahkan untuk mendapatkan likelihood total. Hasil perhitungan likelihood pada data Mawapres atau data mahasiswa bukan Mawapres kemudian dibagi dengan likelihood total, menghasilkan nilai yang disebut probability, yang merupakan hasil akhir dari perhitungan data testing dan menjadi penentuan apakah seorang mahasiswa layak mendapat gelar Mawapres atau tidak. Apabila nilai probability Mawapres yang didapatkan lebih besar daripada nilai probability tidak Mawapres, maka mahasiswa dapat dinyatakan sebagai Mawapres, begitu pula sebaliknya.

Pada percobaan aplikasi dilakukan dengan membandingkan hasil pengukuran pada data training sejumlah 249 data dengan data training sejumlah 267 data. Data testing yang digunakan sejumlah 7 data mahasiswa. Pada percobaan menggunakan 249 data training, hasil perhitungan data testing menghasilkan 3 data mahasiswa yang tidak termasuk mahasiswa berprestasi dan 4 data mahasiswa yang termasuk mahasiswa berprestasi. Sedangkan pada percobaan menggunakan 267 data training, akan menghasilkan 2 data mahasiswa yang tidak termasuk mahasiswa berprestasi dan 5 data mahasiswa berprestasi. Dalam percobaan menggunakan 249 data training, ada satu data mahasiswa tidak termasuk Mawapres namun setelah dilakukan percobaan menggunakan 267 data training, mahasiswa tersebut termasuk Mawapres. Hal tersebut mengubah jumlah Mawapres yang semula hanya 4 mahasiswa menjadi 5 mahasiswa. Berikut ini adalah data hasil pengujian probabilitas mahasiswa tersebut.

Tabel 4. Tabel rekomendasi Mawapres uji coba 249 data trainiing.

\begin{tabular}{llcc}
\hline \multicolumn{1}{c}{ ITEM } & \multicolumn{1}{c}{ NILAI } & \multicolumn{1}{c}{ MAWAPRES } & TIDAK \\
\hline PRODI & D3 MANAJEMEN INFORMATIKA & 0,397260274000 & 0,300970873800 \\
\hline SEMESTER & 4 & 0,404109589041 & 0,398058252427 \\
\hline JENIS KELAMIN & PEREMPUAN & 0,602739726027 & 0,252427184466 \\
\hline INDEKS PRESTASI & 3.64 & 0,138419077233 & 0,141503996750 \\
\hline JML. PIAGAM & 5 LIKELIHOOD & 0,232346150770 & 0,869196590000 \\
\hline & LIKELIHOOD TOTAL & 0,003111684600 & 0,003359500600 \\
\hline \multicolumn{2}{c}{ PROBABILITY VALUE } & 0,006471185200 & 0,006471185200 \\
\hline
\end{tabular}


Berdasarkan Tabel 4, maka dapat ditarik kesimpulan bahwa data tersebut tidak termasuk sebagai mahasiswa berprestasi karena probabilitas Mawapres lebih kecil dari probabilitas tidak Mawapres.

Tabel 5. Tabel rekomendasi Mawapres uji coba 267 data training.

\begin{tabular}{llcc}
\hline \multicolumn{1}{c}{ ITEM } & \multicolumn{1}{c}{ NILAI } & \multicolumn{1}{c}{ MAWAPRES } & TIDAK \\
\hline PRODI & D3 MANAJEMEN INFORMATIKA & 0,391025641000 & 0,279279279300 \\
\hline SEMESTER & 4 & 0,346153846200 & 0,225225225200 \\
\hline JENIS KELAMIN & PEREMPUAN & 0,391025641000 & 0,306306306300 \\
\hline INDEKS PRESTASI & 3.64 & 0,138419077233 & 0,141503996750 \\
\hline JML. PIAGAM & 5 & 0,232346150770 & 0,869196590000 \\
\hline & LIKELIHOOD & 0,007022019000 & 0,002369727500 \\
\hline & LIKELIHOOD TOTAL & 0,009391746500 & 0,009391746500 \\
\hline & PROBABILITY VALUE & 0,747679784600 & 0,252320215400 \\
\hline
\end{tabular}

Berdasarkan Tabel 5. maka dapat ditarik kesimpulan bahwa data tersebut termasuk sebagai mahasiswa berprestasi karena probabilitas Mawapres lebih besar dari probabilitas tidak Mawapres.

Tabel 6. Akurasi Antara Tabel 4 dan 5

\begin{tabular}{ccc}
\hline \multirow{2}{*}{ Uji Coba } & 249 Data & 267 Data \\
\cline { 2 - 3 } & $7 / 7 * 100 \%=100 \%$ & $6 / 7 * 100 \%=85.71 \%$ \\
\hline
\end{tabular}

Tabel di atas menjelaskan pada percobaan menggunakan 249 data training, hasilnya sama dengan data asli sedangkan pada percobaan menggunakan 267 data hasilnya tidak sama dengan data asli atau kurang akurat dibandingkan dengan pengujian menggunakan 249 data. Hal ini dikarenakan data training yang digunakan mengalami penambahan dari 249 data menjadi 267 data sehingga nilai probabilitas baik probabilitas Prodi, jenis kelamin, semester, indeks prestasi, maupun jumlah piagam pun berubah. Berdasarkan percobaan yang sudah dilakukan pada sistem pendukung keputusan penentuan mahasiswa berprestasi menggunakan metode Naïve Bayes berbasis web, proses pengolahan baik data training maupun data testing dilakukan dalam waktu yang relatif cukup cepat jika dibandingkan dengan menggunakan cara manual yang cenderung memakan waktu lebih lama. Pengguna bisa langsung input data mahasiswa melalui web sistem pendukung keputusan, lalu data yang masuk akan diolah menggunakan metode Naïve Bayes sehingga menghasilkan output berupa keputusan apakah seorang mahasiswa mendapatkan gelar mahasiswa berprestasi atau tidak. Selain itu dengan menggunakan sistem pendukung keputusan berbasis web, jumlah kesalahan yang muncul selama pengolahan data juga dapat terminimalisir karena proses pengolahan data sudah dilakukan secara otomatis pada komputer menggunakan metode Naïve Bayes. Akan tetapi penambahan data training yang di-input pada sistem pendukung keputusan akan mempengaruhi akurasi pembuatan keputusan. Pada percobaan pertama menggunakan 249 data training, sistem pendukung keputusan menghasilkan akurasi 100\%, sementara pada percobaan menggunakan 267 data training, akurasinya berubah menjadi $85.71 \%$.

\section{Kesimpulan}

Adapun kesimpulan yang dapat diambil dari penelitian ini di antaranya sebagai berikut :

1. Pengambilan keputusan menggunakan Naive Bayes sangat bergantung pada data training yang digunakan.

2. Dengan bertambahnya jumlah data maka akan mempengaruhi akurasi dari perhitungan probabilitas.

3. Terdapat dua percobaan yang digunakan untuk menguji akurasi sistem pendukung keputusan untuk menentukan mahasiswa berprestasi dengan metode Naïve Bayes. Pada percobaan pertama menggunakan 249 data training, jumlah akurasi adalah 100\% sedangkan percobaan kedua menggunakan 267 data training menghasilkan akurasi $85.71 \%$.

4. Dengan menggunakan sistem pendukung keputusan dapat mempermudah proses pengambilan keputusan untuk pemilihan mahasiswa berprestasi.

\section{Daftar Pustaka}

[1] S. A. Nulhaqim, R. D. Heryadi, R. Pancasilawan and M. Fedryansyah, "Peranan Perguruan Tinggi Dalam Meningkatkan Kualitas Pendidikan di Indonesia Untuk Menghadapi ASEAN Community 2015," Jurnal Unpad, vol. VI, no. 2, pp. 154-272, 2016. 
[2] D. A. N. Wulan and S. M. Abdullah, "Prokrastinasi Akademik Dalam Penyelesaian Skripsi," Jurnal Sosio-Humaniora, vol. V, no. 1, pp. 55-74, 2014.

[3] R. M. Gusti and A. M. Masykur, "Dinamika Psikologis Mahasiswa Berprestasi: Studi Kualitatif Deskriptif," Jurnal Empati, vol. V, no. 1, pp. 50-54, 2016.

[4] Fitriatien and S. Rahmawati, "Sistem Pendukung Keputusan Mahasiswa Berprestasi Menggunakan Metode TOPSIS," Researchgate, Surabaya, 2017.

[5] Rifqo and M. Husni, "Implementasi Algoritma Naive Bayes Dalam Penentuan Pemberian Kredit," Jurnal Pseudocode, vol. IV, no. 2, pp. 120-128, 2017.

[6] R. W. Pratiwi and Y. S. Nugroho, "Prediksi Rating Film Menggunakan Metode Naive Bayes," Jurnal Teknik Elektro, vol. VIII, no. 2, pp. 60-63, 2016.

[7] T. R. Patil and S. S. Sherekar, "Perfomance Analysis of Naive Bayes and J48 Classification Algorithm for Data Classification," International Journal of Computer Science and Applications, vol. VI, no. 2, pp. 256-261, 2013.

[8] E. Manalu, F. A. Sianturi and M. R. Manalu, "Penerapan Algoritma Naive Bayes untuk Memprediksi Jumlah Produksi Barang Berdasarkan Data Persediaan dan Jumlah Pemesanan Pada CV.Papadan Mama Pastries," Jurnal Mantik Penusa, vol. I, no. 2, pp. 16-21, 2017.

[9] H. Annur, "Klasifikasi Masyarakat Miskin Menggunakan Metode Naive Bayes," ILKOM Jurnal Ilmiah, vol. X, no. 2, pp. 160-165, 2018.

[10] Bustami, "Penerapan Algoritma Naive Bayes Untuk Mengklasifikasi Data Nasabah Asuransi," Jurnal Informatika, vol. VIII, no. 1, pp. 884-898, 2014. 